\title{
Protruding the Viable Instinct of Women in Chitra Banerjee Divakaruni’s Novel Before We Visit the Goddess
}

\author{
B. Shiyamala \\ Research Scholar \\ Periyar University College of Arts \& Science \\ Mettur, Salem, Tamil Nadu, India \\ sweety.shiyamala968@gmail.com
}

Abstract

According to some rational research, women's instinct is tuned with more affirmative determination and fortitude. In her article Cari Romm quoted from the online forum Medical Daily which stated that, "Women, traditionally entrusted with child care, evolved to have stronger, more accurate instincts so as to better protect their offspring from any potential threats". When human instinct leads to greater evolution and becomes a choice to exercise still people particularly women allow its suspension in the long run. This dormancy is elicited by circumstantial gender role and the absence of prospects. The great Indian-American author Chitra Banerjee Divakaruni's novel Before We Visit the Goddess redoubles the feasible ability of women and the demand for exercising their will to excogitate their life. Her novel Before We Visit the Goddess is published in the year of 2017 which proposes the journey of three women who belong to three generations and their phenomenal exertion to give meaning and identity to their life. The three women are Sabitri, Bela and Tara (Mother, Daughter and Granddaughter) exchange a deep bond in spite of their aloofness. They have been discovered to all kind of nippy and sultry emotions. As they start to afford their emotions, it leads to many convulsions as well as idyllic outcomes. Thus, the author wants to empower women to use their instincts for higher purpose rather being an accustomed mortal of linearity. 
Keywords: Survival Instinct, Rights, Choice, Linearity, Premeditation, Phenomenal Exertion. Introduction

On suggesting the reinforced life for women, in one of her books, the famous writer Mary Wollstonecraft states that, "I do not wish them to have power over men; but over themselves" (78). In order to exert their capabilities, women have to amalgamate with the milieu by breaking their conservative notions. Instead of subjecting themselves to an inferior cause like steering men and shielding their modesty, women have to broaden their perspective to focus on their individuality. As long as they remain away from the societal proceedings, they never happen to stimulate their sensible emotions which subsequently fail in producing strong survival instincts. While they continue to be subordinates, they become addicted to the role of satiating their needs like food, clothes and shelter. Thus, the phenomenal growth of a society through a communal endeavour will limp due to the deflective part of women who comprise half of the human mass.

This paper will enlighten the voluntary involvement and style of three female protagonists in breaking boundaries. Their willingness in accepting the changes and ability to overcome their past helps them to reconstruct a new life for them. Overtly, the three women get wisdom about the meaning of success and they attain it with strenuous effort. Before We Visit the Goddess narrates a usual storyline which starts with Sabitri's dream on education and later on love life. As a daughter of a temple priest and confectioner, Sabitri's desire for education and belief on future makes her to bear the weight of poor and worriment condition of her family. This emotion hits her hard and as an effect of her instinct Sabitri goes to Kolkata for higher education. Moreover, her mother Durga keeps on motivating Sabitri to pursue her dream against all odds and others opinions. Her mother strongly believes that education and job will enlighten the future of Sabitri. On highlighting the importance of education, Mary Wollstonecraft states, "That a proper education; or, to speak with more 
precision, a well stored mind, would enable a woman to support a single life with dignity, I grant" (44).

Being a Charity Case

Leelamoyi, a rich and an imperialist landlady of Sabitri's village has appreciated the sweets made by Durga a lot. So she agrees to sponsor Sabitri's higher education in Kolkata out of haughtiness. Though Sabitri detests Leelamoyi's attitude, she is appeased by her sponsorship and accommodation at her Kolkata house. Ostensibly, Sabitri and her family really admired Leelamoyi's charity. Later Sabitri understands that it is just an impulse of Leelamoyi as she goes through many hapless experiences in the house. Her needs and affairs have been decided by the hou sehold servants accordingly. The only instinct that keeps her balance is her mother's words "Good daughters are fortunate lamps, brightening the family's name" (Divakaruni 11). As Sabitri’s emotions are outweighed by estrangement and responsibilities, she becomes more wilful to achieve against all odds. Thus she does study well. Instead of settling with what she has, Sabitri wants to attain the next level. Hate, a Survival Instinct

Sabitri’s relationship with Rajiv gives her hope and stimulation of becoming the mistress of the hou sehold. The joyful emotion of love frees Sabitri from aloofness as well as responsibilities. She is no more distinct from other women. When Rajiv tells her that he is happy for having her to talk, Sabitri feels, "This, then, was why he loved her. She was his confessional, his absolution. She had never felt so necessary" (Divakaruni 17). But soon their romance has been discovered by Leelamoyi who abased Sabitri as "conniving slut, harlot's daughter, poisonous snake in my bosom" (Divakaruni19). Leelamoyi blasted her for having schemed Rajiv and forgotten her status. Thus Sabitri is thrown away on the street. Sabitri's humiliations and shame which are the outcomes of her love affair with the heir of Leelamoyi’s family Rajiv, has made vengeance and deception as her survival instincts. 
As Sabitri is not able to forget the shame and forgive Leelamoyi, her heart and mind gets transformed from the way it used to be. She is provoked by anger and retribution. This strong emotion has driven her to deceive her Maths professor Mr. Bijan to succeed in her plan. She wants to survive at any cost to payback for the insult. She becomes a dropout and marries Bijan who loves and believes her naively. Sabitri's has given up her qualities and moral consciousness to avenge her humiliation. Her bitter and painful experience lasts even until she becomes a mother of a six year old girl named Bela. Even though Bijan and her family members motivated Sabitri to continue her education, she deliberately wanted to have a child as she had known already that Leelamoyi couldn't become a grandmother. She undertakes every method to wound Leelamoyi and let her suffer for acting unchivalrously. But this instinct has failed and shattered her schemes after her meeting with Leelamoyi who becomes a limbo. Later Sabitri says, "One good thing had come out of all this. I'd exorcised a demon. I would no longer lie awake at night, remembering Leelamoyi's twisted face as she called me a whore" (Divakaruni 28).

Recapitulatory Fate

Sabitri had lost her husband when Bela was in her teenage. This unsupportable situation strengthens her willpower instead of making her as a passive single parent. She has worked hard and more determined in bringing up Bela. Sabitri designs her purpose of life in spite of becoming a victim of the situation or choosing another life. Her survival instinct creates her as an entrepreneur. She has started a sweet shop in the name of her mother Durga and the shop gives her an identity and success. Those instincts and experiences failed Sabitri, when Bela fell in love with a chemistry student and a political activist from her college. Bela was deeply in love with Sanjay and that strong emotion made her to become a dropout as her mother. She dauntlessly flew to an alien land America to get united with Sanjay. Though hard 
Sabitri tried to stop Bela from falling into the mishaps, it all went in futile. Sabitri was forced to witness the same bitter experiences again through her daughter.

Love as a survival Instinct

In the alien land, Bela struggles to survive without any qualification and identity. Her only instinct which activates Bela is her love for Sanjay. While explaining the emotion love Mary Wollstonecraft says, "Love, in their bosoms, taking place of every nobler passion, their sole ambition is to be fair, to raise emotion instead of inspiring respect" (Divakaruni 49). In this prevailing situation, Bela comes to know the horrible behaviour of Sanjay, who has joined his hands with his friend Bishu to get rid of their slick tenant out of their house. In order to make them vacate, Sanjay and Bishu have poisoned the tenant's dog and caused nervous strain to their son. This betrayal and injustice caused Bela to doubt her instinct of love which has been driving her all along. Due to this controversial aspect, Bela and Sanjay got separated and their daughter Tara sank in depression and loss. Having repulsed by the separation of Sanjay and Tara, Bela leads an unwilled life.

Art of Living

But after meeting Kenneth- a gay, Bela is filled with a desire of living and starts to retrieve her longed life. She wants to stop regretting her acts and make some memorable events for celebrating her aged days. She has started her cooking demonstration segments under the name 'Bela's Kitchen'. This instinct gives her a hope where Kenneth's care and support plays a prominent role in her transmutation. For instance, while trying her old outfit; she says to Kenneth, "Surprised you, didn't I? I cheated and let out the sides. I figured it'll never fit me otherwise. I didn't want to waste any more of my life waiting” (Divakaruni 159). At the same time, Tara's life's gets dismantled due to her parents' divorce. Stimulated by this hard and sudden emotion, stubbornness and hatred becomes her survival instincts. Tara too 
becomes a dropout and falls in love with a foreigner. Unfortunately, she had encountered pain and betrayal in her love life as her mother and grandmother.

Both mother and daughter have learned to master their emotions and stipulate their needs as well. Though their path to prove themselves may differ or easily influential, yet they become successful in the main agenda of establishing themselves as winners of their struggles. They have learned the art of living and knowing oneself. The scope of the paper is letting the woman to acknowledge their imperfections and to fathom their perfections instead of aggrieving and struggling to perfect themselves. They don't want to be dolls which possess perfection in physique as well in accepting the decrees. They claim the idea of functioning one among the human race which exists on knowledge, freedom, and choice.

Hoping a New Beginning

Tara, as a failure lives her life by doing part time jobs with no one loyal beside her. During one of her job as a driver, she has met Dr. Venkatachalapathi from India. This encounter transcends Tara's notion about life and relationships. On their way back from a temple, they met a car accident. Though they could survive the disaster, Tara's hatred and stubbornness is superseded by acceptance of the past and hope of a new beginning. When she thinks that what if the accident endangered her life, she couldn't bear the anxiety and fright. As per the opinion of Dr. Berger, Tara's therapist, she has been informed that being close to death will be a catalyst of undergoing changes in one's survival instinct. Thus she learns that life is too short to hold grudges and hatred, she moves on with her life. She gets married and delivered a boy. Having realised her responsibilities, Tara reunites with her mother Bela. Even she cures of her Kleptomania.

This paper furnishes the need of bringing development to the race of humans. Though there are many doors for women, knowing themselves will alone help them to knock the right door of prosperity. But that understanding demands the courage of doing experiments and 
willpower to regulate their behaviour throughout the process. Thus, the author speaks about enervation as well as the remedies to convalesce the mind and body. Making choices should not fall under the aspect of declaring decrees of one particular gender or group. The skill of decision making should be encouraged among women through imbibing the positive liberty within them. It will provide control over their lives as well as cognize their fundamental aim of life.

Conclusion

Thus, the three women have met all ebbs and flows through following their instincts. The author presented the protagonists as headstrong but not as perfect beings, which shows that they may lack in many resources and at the same time they possess willpower and desire to strive for their success. When Sabitri finds out a new sweet recipe, she has realised that what is meant as accomplishing an achievement. Then she refers it in the letter for Tara, "The smooth, creamy flavour of fruit and milk, sugar and saffron mingled and melted on my tongue satisfaction overwhelmed me... No one could take it away. That's what I want for you, my Tara, my Bela” (Divakaruni 208). Similarly, Bela succeeds in framing her second chance of her life through Bela's kitchen and Tara too overcomes her bitter past and pain. Instead of running from facing the truth, they gradually accept and subdue it. 


\section{Works Cited}

Divakaruni, Chitra Banerjee. Before We Visit the Goddess, Simon\& Schuster UK Ltd, India, New Delhi. 2016.

Romm, Cari. “The Cut: Here's One Theory for What 'Women's Intuition' Really Is" 25, October 2016, www.thecut.com/2016/10/heres-one-theory-for-what-womens-intuition-really-is.html Wollstonecraft, Mary. A Vindication of the Rights of Women. Print land Digital, New Delhi. 2015. 